\title{
New concepts in the therapy of atrial fibrillation
}

\author{
Giuseppe Cocco, Paul Jerie \\ Cardiology Office, Rheinfelden, Switzerland
}

\begin{abstract}
Atrial fibrillation is a frequent arrhythmia with increasing prevalence. The paper reviews the most important present aspects and paradigms in the treatment of the arrhythmia. The main aim of treatment is directed to improve the quality of life while reducing morbidity and mortality. A large experience derived from epidemiological registers and clinical research, impressive advances in interventional electrophysiological therapies and the introduction of non-vitamin $K$ antagonists had a dramatic impact on the medical approach. Recommended steps to classify and treat atrial fibrillation are presented and discussed. (Cardiol J 2016; 23, 1: 3-11)
\end{abstract}

Key words: atrial fibrillation

\section{Introduction}

Atrial fibrillation (AF) is a common arrhythmia. At present AF affects up to $2 \%$ of the general population [1] and in Europe has an estimated prevalence of 6 million. In United States, AF incidence will double, from 1.2 million cases in 2010 to 2.6 million cases in 2030 and given this increase in incidence, $\mathrm{AF}$ prevalence is projected to increase from 5.2 million in 2010 to 12.1 million cases in 2030 [2]. Its frequency is augmenting due to the worldwide increasing patients' age and contributing cardiovascular risk factors [2,3]. Data on AF would fill a textbook. We review the most important recent aspects.

\section{Diagnosis and risk stratification}

The recommended steps to classify and treat AF (Table 1) are a) anamnesis and clinical findings, to diagnose whether $\mathrm{AF}$ is paroxysmal, persistent, long-standing ( > 1 year), or permanent; b) a clinical and laboratory check-up; c) a 12-lead electrocardiogram (ECG); d) an echocardiographic assessment, and e) a long-term dynamic ECG $[1,3]$.

The main aim of treatment of $\mathrm{AF}$ is directed to increase the quality of life while reducing mor- bidity and mortality. The degree of symptoms and co-existing pathologies are the basis for choosing the therapy. A large experience, derived from epidemiological registers and clinical research, impressive advances in interventional electrophysiological therapies, and the introduction of non-vitamin $\mathrm{K}$ antagonists (NOAC) had a dramatic impact in the medical approach [4-7].

\section{Thromboembolic prophylaxis}

The reduction of thromboembolic complications is a capital aim of therapy. The $\mathrm{CHA}_{2}-\mathrm{DS}_{2}$ -VASc score (Table 2), developed when only vitamin $\mathrm{K}$ antagonists (VKA) and antiplatelet agents were available [1, 3-5] and also used for NOAC has replaced previous scores and influences the thromboembolic prophylaxis in $\mathrm{AF}$ [5].

\section{Antiplatelet agents}

The use of aspirin, other antiplatelet agents, or their combination in the thromboembolic prophylaxis in AF is now generally not recommended. The therapeutic effect is uncertain or insufficient and yet there is an increased bleeding risk [1, 3-7].

Address for correspondence: Giuseppe Cocco, MD, Cardiology Office, Marktgasse 10A, CH-4310 Rheinfelden, Switzerland, tel: +00 416183145 55; fax: +00 416183397 56, e-mail: praxis@cocco.ch

Received: 21.07.2015 Accepted: 30.07.2015 
Table 1. Recommended steps to classify and treat atrial fibrillation.

\begin{tabular}{|c|c|}
\hline Diagnosis & Therapy \\
\hline $\begin{array}{l}\text { General } \\
\text { - Symptoms (EHRA score) } \\
\text { - Clinical check-up } \\
\text { - Coexisting pathologies? } \\
\text { - Laboratory } \\
\text { Specific } \\
\text { - 12-lead ECG } \\
\text { - Echocardiography } \\
\text { - Long-term dynamic ECG }\end{array}$ & $\begin{array}{l}\text { Anticoagulation } \\
\text { - } \mathrm{CHA}_{2}-\mathrm{DS}_{2} \text {-VASc score } \\
\text { - Oral anticoagulation (VKA, NOAC) } \\
\text { Antiarrhythmic strategies } \\
\text { - Drugs controlling heart rate } \\
\text { - Sinus conversion if indicated and possible } \\
\text { - Catheter ablation when indicated } \\
\text { Treatment of co-morbidities } \\
\text { - Heart failure } \\
\text { - Hypertension } \\
\text { - Diabetes mellitus } \\
\text { - Apnea/hypopnea } \\
\text { - Respiratory pathology } \\
\text { - Renal failure } \\
\text { - Dyslipidemia } \\
\text { - Inflammatory pathology }\end{array}$ \\
\hline
\end{tabular}

ECG - electrocardiogram; NOAC - non-vitamin K antagonists; VKA — vitamin K antagonists

Table 2. $\mathrm{CHA}_{2}-\mathrm{DS}_{2}$-VASc score.

\begin{tabular}{llc}
\hline Letter & Explanation & Points \\
\hline $\mathrm{C}$ & $\begin{array}{l}\text { Congestive heart failure, } \\
\text { also treated }\end{array}$ & 1 \\
$\mathrm{H}$ & Hypertension, also treated & 1 \\
$\mathrm{~A}_{2}$ & Age $>$ 75 years & 2 \\
$\mathrm{D}$ & Diabetes mellitus, also treated) & 1 \\
$\mathrm{~S}_{2}$ & Stroke: transient ischemic & 2 \\
& attacks/stroke, cerebral stroke & \\
$\mathrm{V}$ & Vascular disease, also treated & 1 \\
$\mathrm{~A}$ & Age, 65-74 years & 1 \\
$\mathrm{~S}$ & Sex, female & 1 \\
\hline
\end{tabular}

$\geq 2$ points $=$ indication for anticoagulation

Table 3. Yearly cardio-embolic risk and $\mathrm{CHA}_{2}$-DS - -VASc score.

\begin{tabular}{lc}
\hline Score & Yearly \% risk \\
\hline 2 & 4 \\
3 & 5 \\
4 & 8.5 \\
5 & 12.5 \\
6 & 18.2 \\
\hline
\end{tabular}

Table 4. HAS-BLED score.

\begin{tabular}{llc}
\hline Letter & Explanation & Points \\
\hline $\mathrm{H}$ & Hypertension, also treated & 1 \\
$\mathrm{~A}$ & $\begin{array}{l}\text { Abnormal renal or liver function } \\
\text { (1 point each) }\end{array}$ & $1-2$ \\
$\mathrm{~S}$ & $\begin{array}{l}\text { Stroke: transient ischemic } \\
\text { attacks/stroke, cerebral stroke }\end{array}$ & 1 \\
$\mathrm{~B}$ & Bleeding & 1 \\
$\mathrm{~L}$ & $\begin{array}{l}\text { Labile international normalized } \\
\text { ratio (for VKA) }\end{array}$ & 1 \\
$\mathrm{E}$ & Age $>$ 65 years & 1 \\
$\mathrm{D}$ & Drugs or alcohol (1 point each) & $1-2$ \\
\hline
\end{tabular}

Maximum 9 points; VKA - vitamin $\mathrm{K}$ antagonists

\section{Oral anticoagulation}

Oral anticoagulation (OAC) is indicated with a $\mathrm{CHA}_{2}$ - $\mathrm{DS}_{2}$-VASc score $\geq 2$. The yearly stroke rate is related to the score as shown in Table 3. However, before using OAC it is necessary to consider general bleeding and safety profiles, and also possible interactions. It is recommended to use the HAS-BLED score (Table 4).

\section{Vitamin $\mathrm{K}$ antagonists}

These drugs are loosely called VKA because they inhibit vitamin $\mathrm{K}$ epoxide reductase. Their 
Table 5. Relevant pharmacokinetics of acenocoumarol, phenprocoumon and warfarin.

\begin{tabular}{|c|c|c|c|}
\hline & Acenocoumarol & Phenprocoumon & Warfarin \\
\hline Clot formation & Yes* & Yes* & Yes* \\
\hline \multirow[t]{2}{*}{ Inhibition** } & $\begin{array}{l}\text { The liver enzyme vit. } \mathrm{K} \\
\text { reductase (thus reduced } \\
\text { form of vit. } \mathrm{KH} 2 \text { ) }\end{array}$ & $\begin{array}{l}\text { The liver enzyme vit. } \mathrm{K} \\
\text { reductase (thus reduced } \\
\text { form of vit. } \mathrm{KH} 2 \text { ) }\end{array}$ & $\begin{array}{l}\text { The liver enzyme vit. } \mathrm{K} \\
\text { reductase (thus reduced } \\
\text { form of vit. } \mathrm{KH} \text { ) }\end{array}$ \\
\hline & $\begin{array}{l}\text { Factors II, VII, IX, and X, } \\
\text { ultimately reduced cleavage } \\
\text { of fibrinogen into fibrin and } \\
\text { decreased coagulability } \\
\text { of the blood }\end{array}$ & $\begin{array}{l}\text { Factors II, VII, IX, and X, } \\
\text { ultimately reduced cleavage } \\
\text { of fibrinogen into fibrin and } \\
\text { decreased coagulability } \\
\text { of the blood }\end{array}$ & $\begin{array}{l}\text { Factors II, VII, IX, and X, } \\
\text { ultimately reduced cleavage } \\
\text { of fibrinogen into fibrin and } \\
\text { decreased coagulability } \\
\text { of the blood }\end{array}$ \\
\hline Dose adjustment & Individual & Individual & Individual \\
\hline \multirow[t]{2}{*}{ Activity*** } & $\begin{array}{c}\text { Effects of genetic factors: } \\
\text { unknown }\end{array}$ & $\begin{array}{c}\text { Effects of genetic factors: } \\
\text { unknown }\end{array}$ & $\begin{array}{l}\text { Activity is determined } \\
\text { partially by genetic factors }\end{array}$ \\
\hline & $\begin{array}{c}\text { Patients older than } 60 \text { years } \\
\text { and Asian patients appear to } \\
\text { exhibit greater than expected } \\
\text { INR response to the } \\
\text { anticoagulant effects VKA }\end{array}$ & $\begin{array}{c}\text { Patients older than } 60 \text { years } \\
\text { and Asian patients appear to } \\
\text { exhibit greater than expected } \\
\text { INR response to the } \\
\text { anticoagulant effects VKA }\end{array}$ & $\begin{array}{c}\text { Patients older than } 60 \text { years } \\
\text { and Asian patients appear to } \\
\text { exhibit greater than expected } \\
\text { INR response to the } \\
\text { anticoagulant effects VKA }\end{array}$ \\
\hline Half-life & $8 \pm 0.5 \mathrm{~h}$ & $157 \pm 12 \mathrm{~h}$ & Mean 40 h (range $20-60$ h) \\
\hline Routine monitoring & Mandatory, INR & Mandatory, INR & Mandatory, INR \\
\hline \multirow[t]{2}{*}{ Interactions } & $\begin{array}{l}\text { Cytochrome P450: } \\
2 \mathrm{C} 9 \text { and } 2 \mathrm{C} 8\end{array}$ & $\begin{array}{l}\text { Cytochrome P450: } \\
2 \mathrm{C} 9 \text { and } 2 \mathrm{C} 8\end{array}$ & $\begin{array}{l}\text { CYP450: 2C9, 2C19, 2C8, } \\
\text { 2C18, 1A2, and 3A4 }\end{array}$ \\
\hline & Vitamin K & Vitamin K & Vitamin $\mathrm{K}$ \\
\hline
\end{tabular}

*When newly started, VKA may promote clot formation temporarily, because the level of protein $\mathrm{C}$ and protein $\mathrm{S}$ are also dependent on vit. $\mathrm{K}$ activity. For example, warfarin causes decline in protein $\mathrm{C}$ levels in first $36 \mathrm{~h}$. In addition, reduced levels of protein $\mathrm{S}$ lead to a reduction in activity of protein $C$ (for which it is the co-factor) and to a reduced degradation of factor Va and factor VIIla. The hemostasis system becomes temporarily shifted towards thrombus formation, leading to a prothrombotic state; ${ }^{*}$ Full doses of VKA produce a precipitous decline in factor VII, resulting in an initial prolongation of the INR. Full antithrombotic effect does not take place until significant reduction in factor II occurs (4-5 days later); ***Polymorphisms in two genes (VKORC1 and CYP2C9) play a particularly large role in response to warfarin. However, the clinical use of pharmacogenomic testing in warfarin dosing is controversial; INR - international normalized ratio; VKA — vitamin K antagonists

action may be antagonized by administration of vitamin K. In some countries non-coumarin VKA, especially 1,3-indandione derivatives (e.g., fluindione and phenindione) are available. However, 4-hydroxycoumarins (coumarins), especially warfarin, are the commonly used VKA. Especially in some European countries, acenocoumarol and phenprocoumon are frequently used. VKA are still used, but the number of patients with AF who are first treated with NOAC or are switched from VKA to NOAC is steadily increasing. VKA are given with an individualized dosage in patients with $\mathrm{AF}$ to reach an international normalized ratio (INR) 2-3. It is noteworthy that to avoid the early prothrombotic state induced by VKA until a therapeutic INR is achieved [8] patients who are at high risk of cardioembolic events should receive a bridging therapy with low-molecular heparins in the early phase (4-5 days) of treatment, or should directly be treated with an NOAC (Table 5).

It should also be considered that OAC with VKA is problematic in patients with severe hepatic dysfunction: under this condition the validity of the prothrombin-time test and related tests for assessing the risk of hemorrhage and guiding OAC is strongly questioned [9] and this conditions may explain the problems related to the use of VKA in this pathology.

Vitamin K antagonists are highly effective in reducing thromboembolic complications in patients with AF [1, 3-7]. However, patients must take VKA throughout their lives and as with any other therapy there are also some 'shadows'. It has been known since in the 1970s that women receiving VKA between the $6^{\text {th }}$ and $12^{\text {th }}$ week of pregnancy give birth to children with severe bone abnormalities. Recently it has been demonstrated that patients on coumarin-therapy develop cardiac valvular pathologies induced by basophilic-amorphous calcified deposits; it is hypothesized that treatment with coumarins induces incomplete $\gamma$-carboxylation of the matrix-gla protein with a consequent decreased protection against tissue calcification [10]. Furthermore, more vitamin $\mathrm{K}$ is needed for carboxylation of bone production than for activation of clotting factor and concern has arisen that VKA could interfere with bone metabolism, putting patients at risk for osteoporosis. The impact of VKA 
Table 6. Pharmacokinetics of available non-vitamin K antagonists.

\begin{tabular}{|c|c|c|c|c|}
\hline & Dabigatran & Apixaban & Edoxaban & Rivaroxaban \\
\hline Inhibition & Thrombin & Factor Xa & Factor Xa & Factor Xa \\
\hline Prodrug & Yes & No & No & No \\
\hline Dose adjustment & $\begin{array}{l}\text { Related to age } \\
\text { and eGFR }\end{array}$ & $\begin{array}{l}\text { Related to age, } \\
\text { eGFR and weight }\end{array}$ & $\begin{array}{l}\text { Related to eGFR, } \\
\text { co-medication } \\
\text { and weight }\end{array}$ & Related to eGFR \\
\hline Bioavailability & $6 \%$ & $70 \%$ & $62 \%$ & $80 \%$ \\
\hline Protein binding & $35 \%$ & $90 \%$ & $55 \%$ & $90 \%$ \\
\hline Dosage intervals & bid & bid & oad & oad \\
\hline Half-life & $12-14 \mathrm{~h}$ & $12 \mathrm{~h}$ & $8-10 \mathrm{~h}$ & $7-11 \mathrm{~h}$ \\
\hline Renal excretion & $40 \%$ & $25 \%$ & $40 \%$ & $35 \%$ \\
\hline Routine monitoring & No & No & No & No \\
\hline Interactions & p-glycoprotein & $\begin{array}{l}\text { cytochrome P3A4 } \\
\text { and p-glycoprotein }\end{array}$ & $\begin{array}{l}\text { cytochrome P3A4 } \\
\text { and p-glycoprotein }\end{array}$ & $\begin{array}{l}\text { cytochrome P3A4 } \\
\text { and p-glycoprotein }\end{array}$ \\
\hline
\end{tabular}

eGFR — estimated glomerular filtration rate; bid — twice per day; oad — once per day

in this setting is not well established, but there is evidence that these drugs have a negative effect on bone turnover [11].

\section{Non-vitamin $\mathrm{K}$ antagonists}

Non-vitamin K antagonists were mentioned in the 2010 guidelines of the European Society of Cardiology. In the 2015 guidelines, one finds 15 suggestions about the use of NOAC in different scenarios. In our paper, we deal only with the use of NOAC in prevention of thromboembolic events in patients with AF. Large data from the use of NOAC have revolutionized and simplified OAC. At present available NOAC are dabigatran, apixaban, edoxaban and rivaroxaban. Their most important pharmacokinetic data are shown in Table 6 . The available data $[5,6]$ show that NOAC are equivalent and possibly better than VKA in the thromboembolic prophylaxis of patients with $\mathrm{AF}$. Of note, compared to VKA, NOAC have a smaller risk for intracerebral bleeding $[6,7,12,13]$.

The mechanism of action of dabigatran differs from that of other available NOAC because it blocks directly and selectively thrombin. The most commonly reported side-effects of dabigatran are gastro-intestinal adverse-effects. When compared to people treated with VKA, patients taking dabigatran had fewer life-threatening bleeds, fewer minor and major bleeds, including intracranial bleeds, but the rate of gastro-intestinal bleeding was significantly higher. Dabigatran capsules contain tartaric acid, which is required for adequate absorption and lowers the gastric $\mathrm{pH}$. The lower $\mathrm{pH}$ has been associated with dyspepsia and it is hypothesized that this plays a role in the increased risk of gastrointestinal bleeding. A small but significantly increased risk of acute coronary events has been noted when combining the safety outcome data from multiple trials [14].

Apixaban, edoxaban and rivaroxaban exert their anticoagulant effect via direct inhibition of a single factor (factor Xa). Major bleeding and fatal bleeding occurred significantly less frequently with these NOAC than with VKA, but gastro-intestinal and nasal bleeding is not rare [15-17]. It is hypothesized that these side effects may be related to anticoagulatory active metabolites, which are absent in VKA. Rare side effects of edoxaban are abnormal liver function and rash [16]. Non-bleeding gastro-intestinal adverse effects of rivaroxaban (e.g. nausea) are very rare [17].

A recent interesting paper [17] with data collected from countries with a reputed experience in the therapy with VKA shows that patients switched from VKA to NOAC have higher stroke risk profiles than patients directly treated with NOAC. Therefore, it seems possible that patients with $\mathrm{AF}$ who have been previously treated with VKA are different from those who have been untreated [18].

When using OAC it is important to consider the renal and to a certain extent the hepatic function. We have insufficient reports about the use of NOAC in patients with severe renal and/or hepatic dysfunction. It is proven, however, that a severe renal dysfunction (and also a severe hepatic dysfunction) may increase the bleeding risk, in NOAC mostly by inducing accumulation [12]. Research for specific antidotes for NOAC is ongoing, but 
Table 7. Antiarrhythmic therapy and/or rhythm control in atrial fibrillation.

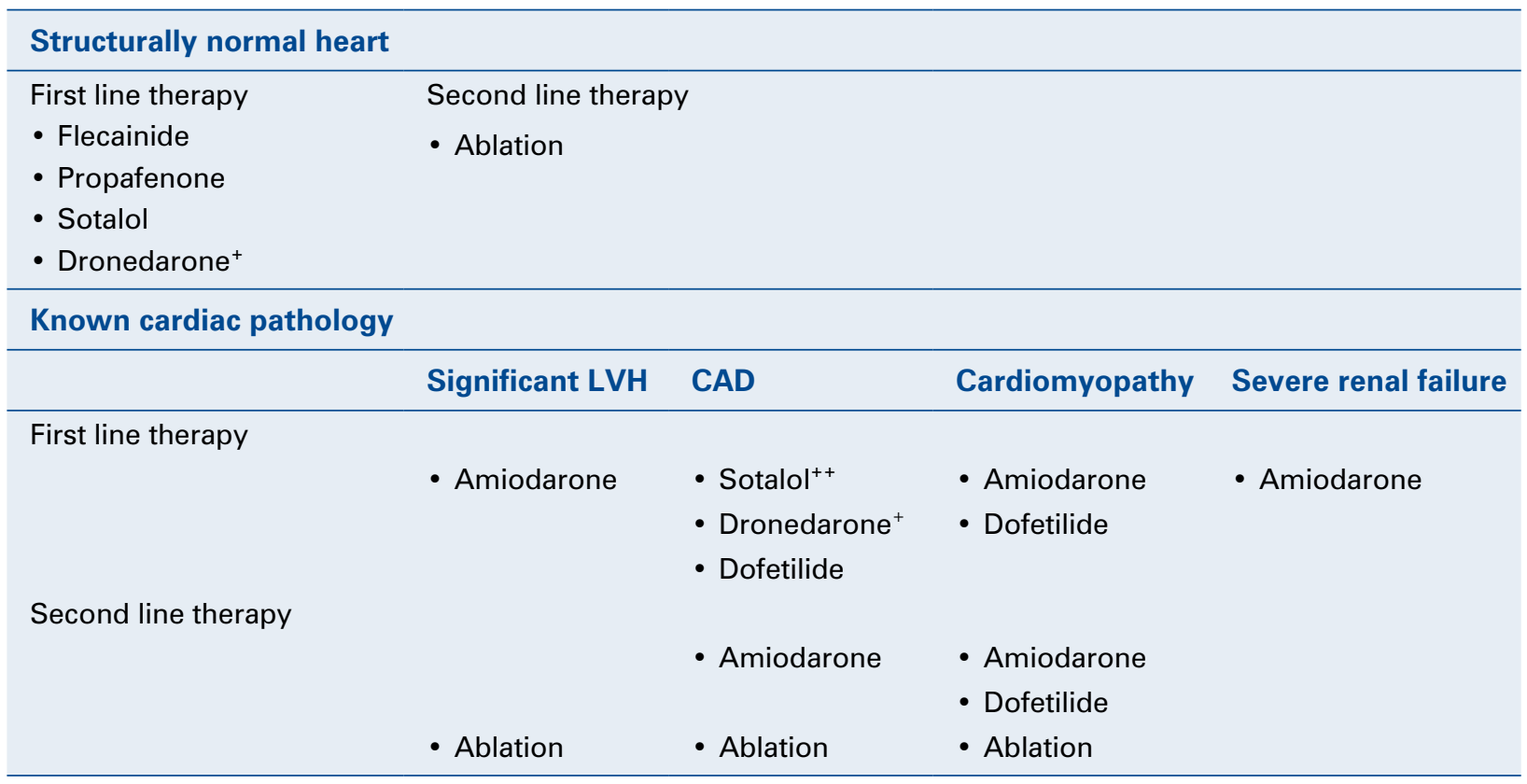

+Dronedarone is contraindicated in patients with long-standing or permanent atrial fibrillation; ++Sotalol is contraindicated in the presence of severely impaired left ventricular function or severe renal failure; CAD — coronary artery disease; LVH — left ventricular hypertrophy

specific antidotes are not yet available with few exceptions in hospital settings. Some patients were successfully treated with prothrombin concentrate complex.

\section{Alternative thromboembolic prophylaxis when oral anticoagulation is contraindicated}

Some patients with AF and high risk for thromboembolic complications cannot be safely treated with OAC because they also have an excessive bleeding risk or contraindicating co-morbidities. Thromboembolic events originate from the left atrium. Thus, in selected patients with $\mathrm{AF}$ in whom necessary OAC is contraindicated, left atrial appendage closure with an occluding device can be used [19-21]. The technique is quite effective in reducing thromboembolic events in $\mathrm{AF}[1,3,4$, 19-21], but several complications may occur [21]. For example, apixaban had to be used to treat protruding thrombus over left atrial appendage occlusion device [22].

\section{Antiarrhythmic therapies}

We have discussed the need for thromboembolic prophylaxis but, of course treatment of the arrhythmia has also a central role. The therapy is adjusted to the symptoms and the duration of the $\mathrm{AF}$, taking into proper account the co-morbidities. Possible therapeutic approaches are presented in Table 7.

\section{Pharmacologic options}

Table 8 shows antiarrhythmic drugs which may be used in the therapy AF. AF is a dynamic disease and altogether available antiarrhythmic drugs have a limited efficacy. Therefore, long-term antiarrhythmic treatment of AF is often less effective than required $[3,4,23]$.

\section{Heart rate control}

In asymptomatic patients and, especially, in the elderly polymorbid patients with $\mathrm{AF}$, heart rate control is often the $1^{\text {st }}$ choice therapeutic option $[3,4,23-25]$.

The use of digoxin is bond to a long-time debate. Especially in recent years, it is stated that, when used in patients with $\mathrm{AF}$ and manifest cardiac failure, digoxin increases the mortality [22-28]. Vamos et al. [28] suggest several potential mechanisms of digoxin-associated mortality increase: in many studies detected digoxin serum levels were higher $(>1.2 \mathrm{ng} / \mathrm{mL}$ ) than the level now recommended; at toxic levels, digoxin may induces severe arrhythmias; digoxin has many interactions, e.g. with amiodarone and other antiarrhythmic drugs (and these drugs were used in the analyzed studies; digoxin increases vagal tone, reduces atrioventricular conduction and shortens atrial refractory periods, effects which may have pro-arrhythmic effects in AF; also, digoxin was found to be associated with doubling of relapses of 
Table 8. Antiarrhythmic drugs used in chronic therapy of atrial fibrillation.

\begin{tabular}{|c|c|c|c|c|}
\hline Class & Example & $\begin{array}{l}\text { Pro-arrhythmic } \\
\text { potential }\end{array}$ & $\begin{array}{l}\text { Other relevant } \\
\text { adverse events }\end{array}$ & Contraindications \\
\hline $\mathrm{IC}^{+}$ & $\begin{array}{l}\text { Flecainide and } \\
\text { propafenone }\end{array}$ & $\begin{array}{l}\text { Atrial flutter with } 1: 1 \text { con- } \\
\text { duction }^{++}, \text {VT/VF }\end{array}$ & $\begin{array}{l}\text { Nausea, dyspepsia, } \\
\text { paresthesia }\end{array}$ & $\begin{array}{l}\text { CAD, LVH, long QT-time, } \\
\text { LVD, HF NYHA IV }\end{array}$ \\
\hline \multirow[t]{6}{*}{ III } & Sotalol & Torsades de pointes & Bradycardia & Severe LVD or severe RF \\
\hline & Dofetilide & Torsades de pointes & & \\
\hline & Dronedarone $^{++}$ & Rare & $\begin{array}{c}\text { Decompensated HF, } \\
\text { hepatic dysfunction (rare) }\end{array}$ & $\begin{array}{l}\text { HF NYHA Il with decom- } \\
\text { pensation in the last weeks, } \\
\text { long QT-time, previous SCD } \\
\text { (with LVD, HF) permanent AF, } \\
\text { relevant hepatic failure or RF }\end{array}$ \\
\hline & Amiodarone & Rare & $\begin{array}{c}\text { Thyroid, lung, hepatic } \\
\text { toxicity, optic neuropathy, } \\
\text { polyneuropathy }\end{array}$ & $\begin{array}{l}\text { Hepatic disease, interstitial } \\
\text { lung disease }\end{array}$ \\
\hline & Digoxin & Possible & $\begin{array}{l}\text { Dizziness, nausea, faint- } \\
\text { ing, pounding, or irregular } \\
\text { heartbeat or pulse, brady- } \\
\text { cardia. Less common: black, } \\
\text { tarry stools, bleeding gums, } \\
\text { blood in the urine or stools, } \\
\text { pinpoint red spots on the } \\
\text { skin, rash with flat lesions or } \\
\text { small raised lesions on the } \\
\text { skin, stomach pain, unusual } \\
\text { bleeding or bruising, gyne- } \\
\text { comastia, anxiety, confusion, } \\
\text { impaired vision }\end{array}$ & $\begin{array}{l}\text { Bradycardia, relevant RF } \\
\text { or hepatic failure, } \\
\text { electrolyte pathologies }\end{array}$ \\
\hline & & Toxicity & Proarrhythmic effect & \\
\hline
\end{tabular}

+To counteract this pro-arrhythmic effect of IC class agents should be used in combination with drugs which reduces the AV-conduction ( $\beta$-blocker, verapamil or diltiazem); + +Dronedarone is contraindicated in patients with long-standing or permanent atrial fibrillation (AF); CAD - coronary artery disease; HF — heart failure; LVD — left ventricular dysfunction; LVH — left ventricular hypertrophy; NYHA - New York Heart Association; RF — renal failure; SCD — sudden cardiac death; VF — ventricular fibrillation; VT — ventricular tachycardia

AF following cardioversion. However, the statistically increased mortality in AF-patients treated with digoxin is open to debate [29-33]. Digoxin has been used for a long time, mostly in polymorbid patients, when other drugs have failed and there is no alternative pharmacologic treatment. It is well known that the therapeutic safety profile of digoxin is narrow, and overdose and/or an interaction with antiarrhythmic drugs, diuretics etc. may induce toxic effects. Most recent studies describe dangerous electrophysiological effects which were described as digoxin-induced arrhythmias, but the serum levels were higher than safe, the electrolytic state $\left(\mathrm{K}^{+}, \mathrm{Na}^{+}\right.$etc. $)$were rarely reported: were the arrhythmias evidence for toxicity? Adverse-events due to improper use and toxicity should not be taken and evidence for increased mortality at lowdose levels. Meta-analysis studies reporting effects and increased mortality of digoxin are difficult to be evaluated, because the use of digoxin and the treated patients cannot be properly compared [32, 33]. Indeed, if properly titrated, taking into account digoxin pharmacokinetics and the co-morbidities (renal function, electrolytes) digoxin is effective in improving cardiac symptoms and (even not during physical exercise) it has a regulatory effect on heart rate. The impetus for novel methodologies regarding analysis and reporting of results should not solely be driven by concerns of statistical power, but by a desire to better understand how therapies influence a broader characterization of total disease burden. Most disease progressions are associated with the realization of multiple complications and analysis may sometimes obfuscate the findings. Analysis of event arms may lend itself to conflicting interpretations such as those presented in recent trials, there is the concern of type I error rate inflation due to multiple testing [34]. Thus, the reader is cautioned with this approach [34]. An exclusive focus on mortality may obscure important effects of medications [35]. Thus, the real effect of old digoxin on increased mortality (especially in polymorbid elderly patients) must be taken into consideration. Using two standardized 
bias scoring systems, D. Kotecha (annual congress of the ESC in London 2015) has demonstrated that reviews reporting an association between mortality and digoxin were highly biased. No studies have evaluated the impact of digoxin in patients with $\mathrm{AF}$ without heart failure. The higher the observational study's bias score, the greater the reported association between digoxin and mortality. In contrast, well conducted and randomized controlled trials all score a very low bias and carry a consistent message that digoxin had a neutral effect on mortality. The best available evidence demonstrates that digoxin reduces hospital admission and has no effect upon all-cause mortality in patients with heart failure with or without atrial fibrillation.

\section{Pharmacologic therapy aimed to restore/maintain sinus rhythm}

First choice drugs are $\beta$-blockers or, when contraindicated, verapamil or diltiazem [3, 4, 23-26].

Asymptomatic patients and patients with impaired cardiac function often are effectively treated with a rhythm control strategy [1, 3, 22-25].

In patients with AF without structural cardiac pathology antiarrhythmic agents of class IC (e.g., flecainide or propafenone), combined with a $\beta$-blocker, are the first choice [1]. In patients with relevant cardiac pathology, especially with an impaired left ventricular systolic function, amiodarone and dofetilide (class III antiarrhythmic drugs) are the first choice $[1,4,25]$.

Amiodarone (class III agent) is the most effective therapeutic agent but, unfortunately its use is severely limited because of its many interactions and adverse effects; amiodarone should be used for a relatively short period [3, 4, 23-25].

Dronedarone (class III agent) should be used with many restrictions and is contraindicated in patients with heart failure and in those with permanent AF [4, 5, 23-25].

Vernakalant is a new antiarrhythmic drug that acts selectively in the atrium, targeting atrial specific channels: the Kv1.5 channel which carries IK (ur), and the Kir3.1/3.4 channel which carries IK (Ach): it can also work to block Ito, late Ina, and exert a minor blockade of IKr currents. Vernakalant is available in both intravenous and oral forms. Intravenous vernakalant has been shown to be effective in terminating acute onset $\mathrm{AF}$ whose duration is $>3 \mathrm{~h}$ and $<7$ days ( $\sim 50 \%$ efficacy vs. $10 \%$ for placebo). It does not appear to be effective for $\mathrm{AF}$ whose duration is $>7$ days, nor does it appear to be effective for atrial flutter. Studies with oral vernakalant have been designed to evaluate its efficacy and safety in the prevention of $\mathrm{AF}$ recurrence. Up to date have the therapeutic efficacy was moderate; the most common side effects being dysgeusia, sneezing, paresthesia, nausea, and hypotension. In the clinical trials, there were minimal drug-induced ventricular arrhythmias observed.

\section{Electrophysiological options \\ to achieve sinus rhythm}

The MAZE procedures were the first attempts to obtain and maintain sinus rhythm in AF [36]. A recent review [37] focuses on surgical options in the curative treatment of AF. Especially the hybrid approach, which combines the advantages of catheter and surgical ablation (with the excision or exclusion of the left atrial appendage), is a promising approach for the future. The knowledge about $\mathrm{AF}$ pathophysiology is steadily increasing and new data affect the therapeutic strategies. Because of the increased experience and good therapeutic results catheter-based ablation procedures (isolation of the pulmonary veins either by radiofrequency or cryoablation) have become a routine intervention in cardiology and are increasingly used in AF. Indeed, the ablation therapy is becoming the $1^{\text {st }}$ choice therapy for symptomatic patients with $\mathrm{AF}$ $[1,4,20,36]$. Patients' preferences play without doubt a central role. The efficiency of the ablation is increasing. Nonetheless, the risk-advantage profile must be taken into account and some indications must be respected. The type and duration of AF, the type of cardiac disease, and the size and function of the atria must be considered to deliver a successful therapy. In centers with large numbers of interventions complications occur in less than $4 \%$ of cases. Complications at the inguinal entrance occur in about $2 \%$ of cases. In less than $1 \%$ of cases cardiac tamponade may follow and require drainage. Transient ischemic complications or cerebral strokes occur in less than $1 \%$ of cases. Atrio-esophageal fistula is a feared complication, which occur in less than $0.2 \%$ of cases. Recent meta-analyses $[3,36]$ report that $77 \%$ of the ablation-treated patients are asymptomatic at a 1-year follow-up, in comparison to $52 \%$ of medically treated patients. It should be noted that up to a third of patients requires a $2^{\text {nd }}$ ablation (redo-ablation) to achieve a long-lasting symptom-free life [3, 4, 23, 25, 38]. We still lack enough information to personalize ablation in each individual, which could results in more efficacious and less extensive ablation in some patients [39].

In some cases, pharmacologic treatment does not suffice to reduce sufficiently heart rate. In these 
patients, an approach could be the interruption of the atrioventricular conduction by catheter ablation and the implantation of a cardiac pacemaker [3]. This therapy has a $99 \%$ efficacy and has the advantage that many drugs to control the arrhythmia can be discontinued.

\section{Treatment of risk factors and co-morbidities}

In recent years, the term 'upstream therapy' has been used to describe treatment of $\mathrm{AF}[3,4$, 23-25]. It has been demonstrated that the effective treatment of cardiovascular risk factors (e.g., arterial hypertension, diabetes mellitus, tobacco consumption, sleep apnea/hypopnea, renal dysfunction, pulmonary diseases, inflammatory disorders, and dyslipidemia) has positive therapeutic effects on AF [3-7, 23-26]. A study [40] has shown that, in overweight patients with $\mathrm{AF}$, a significant weight decrease, associated with a good control of metabolic pathologies, reduces symptoms related to $\mathrm{AF}$ and also has a positive effect on cardiac remodeling. Among the drugs used to treat patients with AF it seems that angiotensin-converting enzyme inhibitors/angiotensin- 2 receptor antagonists, and statins (HMG CoA reductase inhibitors) are effective in slowing the evolution of AF. These drugs may reduce pathologic factors such as inflammation and fibrosis.

Lastly, it has been found that non-steroidal anti-inflammatory drugs increase the risk of AF [41] and it might be advisable, if possible, to use other analgesic drugs to treat patients at risk for $\mathrm{AF}$.

\section{Acknowledgements}

We thank Mrs. J. Bugmann for her help and typewriting of the manuscript.

\section{Conflict of interest: None declared}

\section{References}

1. Camm AJ, Lip GYH, De Caterina R et al. Focused update of the ESC Guidelines for the management of atrial fibrillation. Eur Heart J, 2012; 33: 2719-2747, doi: 10.1093/eurheartj/ehs253.

2. Colilla S, Crow A, Petkun W et al. Estimates of current and future incidence and prevalence of atrial fibrillation in the U.S. adult population. Am J Cardiol, 2013; 15: 1142-1147. doi: 10.1016/j. amjcard.2013.05.063.

3. Pillarisetti J, Lakkireddy D. Atrial fibrillation in Europe: State of the state in disease management. Eur Heart J, 2014: 35: 3326-3327. doi: 10.1093/eurheartj/ehu415.

4. Camm AJ, Kirchhof P, Lip GYH et al. Guidelines for the management of atrial fibrillation. The task force for the management of atrial fibrillation of the European Society of Cardiology (ESC). Eur Heart J, 2010; 31: 2369-2429. doi: 10.1093/eurheartj/ehq278.

5. Gage BF, Waterman AD, Shannon W et al. Validation of clinical classification schemes for predicting stroke: Results from the National Registry of Atrial Fibrillation. JAMA, 2001; 285: 2864-2870. doi: 10.1001/jama.285.22.2864.

6. Lip GYH. Stroke and bleeding risk assessment in atrial fibrillation: When, how, and why? Eur Heart J, 2013; 34: 1041-1049. doi: http://dx.doi.org/10.1093/eurheartj/ehs435.

7. Heidbuchel $\mathrm{H}$, Verhamme $\mathrm{P}$, Alings $\mathrm{M}$ et al. EHRA Practical Guide on the use of new oral anticoagulants in patients with nonvalvular atrial fibrillation: Executive summary. Eur Heart J, 2013; 34: 2094-2106. doi: 10.1093/eurheartj/eht134.

8. Diener HC, Granger C, Patel MR. Is there a period of liability with initiation of warfarin in patients with atrial fibrillation? Eur Heart J, 2014; 35: 1834-1835. doi: 10.1093/eurhearti/ehu042.

9. Tripodi A, Mannucci PM. The coagulopathy of chronic liver disease. New Engl J Med, 2011; 14: 147-156.

10. Schurgers LJ, Aebert H, Vermeer $\mathrm{C}$ et al. Oral anticoagulant treatment: Friend or foe in cardiovascular disease? Blood, 2004; 104: 3231-3232. doi: 10.1182/blood-2004-04-1277.

11. Stenova E, Steno B, Killinger $Z$ et al. Effect of long-term oral anticoagulant therapy on bone mineral density and bone turnover markers: A prospective 12 month study. Bratisl Lek Listy, 2011; 112: 71-76.

12. Hart RG, Eikelboom IW, Alistair J et al. Anticoagulants in atrial fibrillation patients with chronic kidney disease. Nat Rev Nephrol, 2012; 8: 569-578.

13. O'Donoghue ML, Ruff CT, Giugliano RP et al. Edoxaban vs. warfarin in vitamin $\mathrm{K}$ antagonist experienced and naive patients with atrial fibrillation. Eur Heart J, 2015; 36: 1470-1477. doi: 10.1093/ eurheartj/ehv014.

14. Uchino K, Hernandez AV; Hernandez. Dabigatran associated with higher risk of acute coronary events - metaanalysis of non inferiority randomized controlled trial. Arch Intern Med, 2012; 5 : 397-302. doi: 10.1001/archinternmed.2011.1666.

15. Granger CB, Alexander JH, John JV, McMurra JJV et al. Apixaban versus warfarin in patients with atrial fibrillation. New Engl J Med, 2011; 365: 981-992.

16. http://www.mayoclinic.org/drugs-supplements/edoxaban-oralroute/side-effects/drg-20137330.

17. http://www.rxlist.com/xarelto-side-effects-drug-center.htm.

18. Podokorney SD, Granger CB. Should patients on vitamin K antagonists be treated differently? Eur Heart J, 2015; 36: 1431-1433. doi: 10.1093/eurheartj/ehv032.

19. Reddy VY, Sievert H, Halperin J et al. Percutaneous left atrial appendage closure vs warfarin for atrial fibrillation: A randomized clinical trial. JAMA, 2014; 312: 1988-1998.

20. John Camm A, Colombo A, Corbucci G et al. Left atrial appendage closure: A new technique for clinical practice. Heart Rhythm, 2014; 11: 514-521.

21. Reddy VY, Holmes D, Doshi SK et al. Safety of percutaneous left atrial appendage closure. Results From the Watchman Left Atrial Appendage System for Embolic Protection in Patients With AF (PROTECT AF) clinical trial and the continued access registry. Circulation, 2011; 123: 417-424. doi: 10.1161/CIRCULATIONAHA.110.976449.

22. Feixa X, Scalone G, Martín-Yuste V, Vidal B. Large protruding thrombus over left atrial appendage occlusion device successfully treated with apixaban. Eur Heart J, 2015; 36: 1427. doi: 10.1093/eurheartj/ehv081. 
23. Kevin M. Trulock, Sanjiv M et al. Rhythm control in heart failure patients with atrial fibrillation. J Am Coll Cardiol, 2014; 64: 710-721. doi: 10.1016/j.jacc.2014.06.1169.

24. Woods CE, Olgin J. Atrial fibrillation therapy now and in the future: drugs, biologicals, and ablation. Circ Res, 2014; 14: 1532-1546.

25. European Heart Rhythm A, European Association for CardioThoracic S, Camm AJ et al. Guidelines for the management of atrial fibrillation: the task force for the management of atrial fibrillation of the European Society of Cardiology (ESC). Eur Heart J, 2010; 19: 2369-2429.

26. Whitbeck MG, Charnigo RJ, Khairy P et al. Increased mortality among patients taking digoxin: analysis from the AFFIRM study. Eur Heart J, 2013; 34: 1481-1488. doi: 10.1093/eurheartj/ehs348.

27. Pastori D, Farcomeni A, Bucci T et al. Digoxin treatment is associated with increased total and cardiovascular mortality in anticoagulated patients with atrial fibrillation. J Cardiol, 2014; 180: 1-5. doi: org/10.106.I.jcard.2014.11.112.

28. Vamos M, Erath JW, Hohnloser SH. Meta-analysis: Digoxin linked to elevated mortality risk in AF, congestive HF. Eur Heart J, 2015; 36: 1831-1838. doi: 10.1093/eurheartj/ehv143.

29. Packer M, Gheorghiade M, Young JB et al. Withdrawal of digoxin therapy from patients treated with angiotensin-converting enzyme inhibitors. N Engl J Med, 1993; 329: 1-7.

30. Ward RE, Gheorghiade M, Young JB. Economic outcomes of withdrawal of digoxin therapy in adult patients with stable congestive heart failure. J Am Coll Cardiol, 1995; 26: 93-101.

31. Ahmed A, Rich MW, Love TE et al. Digoxin and reduction in mortality and hospitalisation in heart failure: A comprehension post hoc analysis of the DIG trial. Eur Heart J, 2006; 27: 178-186. doi: 10.1093/eurheartj/ehi687.
32. Brophy JM. Rehabilitating digoxin. Eur Heart J, 2006; 27: 127-129. doi: 10.1093/eurheartj/ehi686.

33. Murpy SA. When 'digoxin use' is not the same as 'digoxin use': Lesson from the AFFIRM trial. Eur Heart J, 2013; 34: 1465-1467. doi: 10.1093/eurheartj/eht087.

34. Ciolino JD, Carter RE. Reanalysis or redefinition of the hypothesis? Eur Heart J, 2015; 36: 340-341. doi: 10.1093/eurheratj/ehu311.

35. Yusuf S, Negassa A. Choice of clinical outcomes in randomized trials of heart failure therapies: Disease-specific or overall outcomes? Am Heart J, 2002; 143: 22-28.

36. Cox J, Schuessler R, D'Agostino H et al. The surgical treatment of atrial fibrillation. III. Development of a definitive surgical procedure. J Thorac Cardiovasc Surg, 1991; 101: 569-583.

37. Starck CT, Steffel J, Holubec T, Falk V. Current aspects of atrial fibrillation surgery. Cardiovasc Med, 2015; 18: 181-185.

38. Jia Chen J, Lin Y, Chen L et al. A decade of complex fractionated electrograms catheter-based ablation for atrial fibrillation: Literature analysis, meta-analysis and systematic review. Int J Cardiology Heart Vess, 2014; 4: 63-72. doi: 10.1016/j.ijchv.2014.06.013.

39. Mont L. Atrial fibrillation ablation: Less is more? Eur Heart J, 2015; 36: 1792-1793. doi: 10.1093/eurheartj/ehv224.

40. Abed HS, Wittert GA, Leong DP et al. Effect of weight reduction and cardiometabolic risk factor management on symptom burden and severity in patients with atrial fibrillation: A randomized clinical trial. JAMA, 2013; 310: 2050-2060. doi: 10.1001/ jama.2013.280521.

41. Krijthe BP, Heering J, Hofman A et al. Non-steroidal anti-inflammatory drugs and the risk of atrial fibrillation: A population-based follow-up study. BMJ Open, 2014; 4: e004059. doi: 10.1136/ bmjopen-2013-004059. 